\title{
HYDROCHEMICAL STUDY OF THE HOT GROUNDWATER OF AMPELIA AREA, EASTERN THESSALY, GREECE. A NEW AREA WITH GEOTHERMAL INTEREST
}

\author{
Kanellopoulos C. ${ }^{1}$, Christopoulou M. ${ }^{1}$, Vakalopoulos P. ${ }^{1}$, Efthimiopoulos Th. ${ }^{1}$ \\ and Xenakis M. ${ }^{1}$ \\ ${ }^{1}$ Institute of Geology and Mineral Exploration, $1^{\text {st }}$ Spirou Louis St., Olympic Village, 13677, \\ Acharnae,Greece, ckanellopoulos@gmail.com,christopouloumaria@gmail.com,vakalo@igme.gr, \\ efthimio@igme.gr,markxen@igme.gr
}

\begin{abstract}
Ampelia area is a newly discovered area with geothermal interest and no surface manifestations (hidden resource). It is located in Farsala basin and belongs to the Enipeas graben. The geothermal anomaly is related with the E-W trending faults, which mainly control the basin development and the NNW-SSE trending faults of the area. The temperature values from the deep water boreholes (>200m depth) range from 20 to $41^{\circ} \mathrm{C}$. The chemical composition of the studied groundwater samples varies in all chemical parameters. Most of the samples have affected by shallow cold aquifers (high E.C. and $\mathrm{NO}_{3}^{-}$values). The most representative samples $\left(\mathrm{T}>30^{\circ} \mathrm{C}\right)$ are from the deepest boreholes (hydrochemical type $\mathrm{Na}-\mathrm{HCO}_{3}$ ), which cut the fractured crystalline basement, i.e. limestones, flysch and ophiolitic rocks. They present the highest $\mathrm{pH}$ values $(\mathrm{pH}>8)$ and the lowest E.C. compared with the rest of the samples. Their Ni and Cr concentrations are very low, indicating that the groundwater is not in contact with the ultramafic rocks from the ophiolite sequence. According to silica chemical geothermometers for the most representative samples, the expected temperature values of a potential geothermal reservoir range from $\sim 60$ to $100^{\circ} \mathrm{C}$.

Keywords: geothermal energy, hot groundwater geochemistry, trace element and ion concentration, Eastern Thessaly, Greece.
\end{abstract}

\section{Пєрі́ $\eta \psi \eta$}

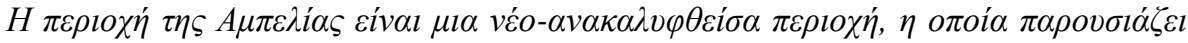

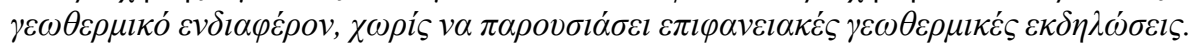

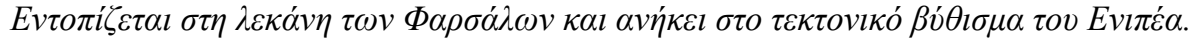

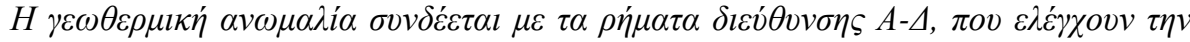

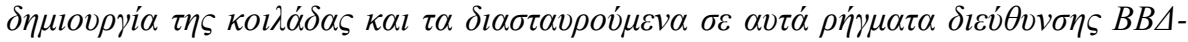

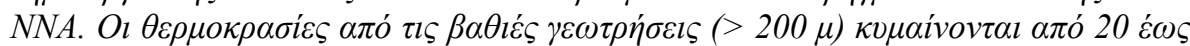





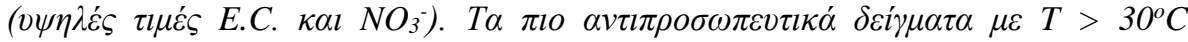

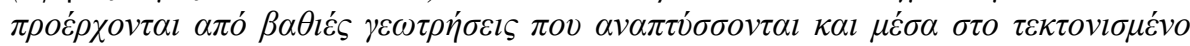

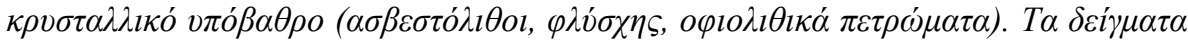

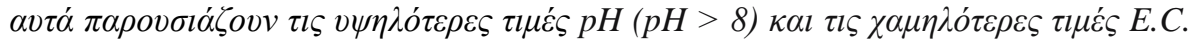

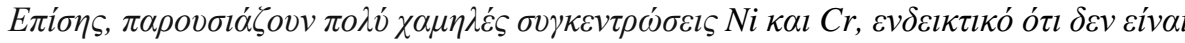

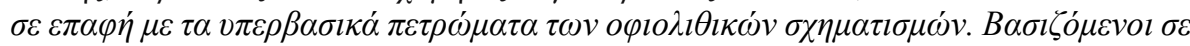




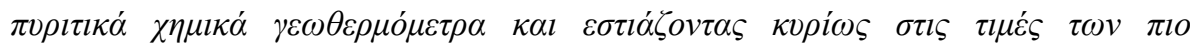

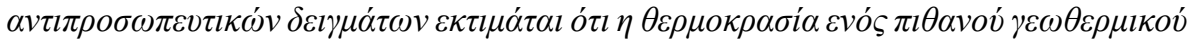

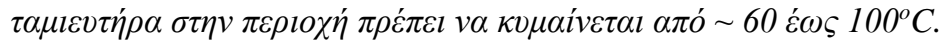

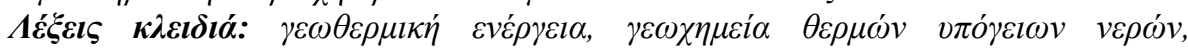

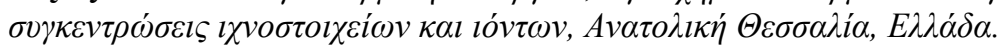

\section{Introduction}

In the next decades, the demand for energy could double or even triple as the global population rises and developing countries expand their economies. This increase coupled with continued demand for the same, limited natural resources will cause significant increase in consumption of energy. All life on Earth depends on energy and the cycling of carbon. Affordable renewable energy resources are essential for economic and social development as well as food production, water supply availability and sustainable healthy living (Glassley, 2015).

That huge demand for energy could be covered by the renewable energy resources, which at the same time have low $\mathrm{CO}_{2}$ emissions. One of them, which Greece is blessed to have in several places due to its geological setting, is the geothermal energy. The high deformation rate of the Aegean area, the combination of magmatic and volcanic processes as well as intense tectonic activity which results in active fault systems, favour the rise of deep hot waters that in many times discharge at the surface as hot springs. In these cases, the areas with geothermal interest are easy to be discovered, by finding hot springs or/and boiling mud pot or/and fumaroles. However, there are many geothermally interesting areas that have little or no surface expression (hidden resources).

The Institute of the Geological and Mineralogical Exploration (IGME) since 1970`s, based on the first systematic study of all known Greek hot springs (Orfanos, 1975; Gioni, 1983; Sfetsos, 1988 etc.), has started to explore different areas of Greece in order to find potentially interesting areas for geothermal energy with no surface manifestations (Taktikos, 1985). One interesting province is Eastern Thessaly, in which there are several areas with hot and mineral springs e.g. Smokovo, Soulanta, Kaitsa and Ekkara. Recently, five new areas were identified to be potentially interesting for geothermal energy i.e. Paschalitsa, Nees Karies, Ampelia, Microthives and Paliouri (hidden resources; Fig.1). Paschalitsa and Nees Karies have explored from IGME with deep boreholes (Xatzis, 2001). The hydrogeology of Farsala basin was studied by Mariolakos et al. (2001a, 2001b). Stamatis et al. (2007) made the first attempt to evaluate the origin and quality of Ampelia thermal groundwaters.

The aim of this paper is to present the results of geothermal research of Ampelia area (Eastern Thessaly, Greece); which is a newly discovered area with geothermal interest and no surface expression and assess the hydrochemical characteristics and geothermometry applications of the hot groundwater of the area.

\section{Geological and hydrological setting}

Ampelia area is located in Eastern Thessaly, in the central part of Greece. The study area lies between the following coordinates X: 364000E, Y: 4356000N and X: 379000E, Y: 4344000N (EGSA 87 ). It is characterized by smooth topography and lowland areas.

Eastern Thessaly belongs geologically to the Sub-Pelagonian geotectonic zone (Aubouin, 1959; Mpornovas et al., 1969; Katsikatsos et al., 1983; Mountrakis, 1986). The study area is located in Farsala basin which is part of the Western Thessaly basin (Fig. 1) and consists of flysch (Upper Cretaceous age), karstified limestones (Upper Cretaceous), ophiolitic rocks including serpentinites, dunites, peridotites; in Farsala area occur pillow lavas and some ultrabassic intense serpentinised formations and schists (southern part of Farsala Basin, Mpornovas et al., 1969, 1964; Katsikatsos et al., 1983). Large parts of Eastern Thessaly are covered by Post Alpine formations i.e. Holocene deposits, Neogene formations and Plio-Pleistocene terrestrial deposits and layers of lignite 
(Giakkoupis, 1995; Dimitriou and Arapogiannis, 2000, Fig. 1). The Post Alpine formations have been detail described by Giakkoupi, 1995. The tectonic structure of the study area is characterized by E-W trending faults, which mainly control the basin development and by NNW-SSE trending faults. Ampelia area belongs to the Enipeas graben. The sediments are mainly Holocene alluvial sands and Pleistocene terrestrial. The alpine basement is formed by flysch, Cretaceous limestone and ophiolitic rocks. The morphology of the top of the basement is controlled by the neotectonic activity, expressed by large folds with axis direction NE-SW as well as by E-W and NW-SE striking faults (Spyridonos et al., 2002).

Mariolakos et al. (2001a, 2001b) and Stamatis et al. (2007) describe the presence three different aquifers in the study area. One unconfined aquifer of important potentiality is developed in the unconsolidated deposits of the basin and suffers from overexploitation due to the supply of the irrigation needs of the area. The thickness of the unconsolidated deposits ranges from a few meters eastern of the basin to a few ten meters westwards, to more than $200 \mathrm{~m}$ in the central and northern parts of the basin, particularly within the tectonic graben (Mariolakos et al., 2001a, 2001b). Groundwater flows from the east to the west parts of the basin. Another karst aquifer of important potentiality is developed within the karstified carbonate formations. The major karst springs of the region, such as Vrisia and Chtouri springs, located west of the Farsala city, are fed from the carbonate formations of Narthakio and Filio Mountain in the west part of the basin (Mariolakos et al., 2001a, 2001b). The carbonate masses developed in the east part of the basin probably feed laterally the unconsolidated formations of the basin. Also, an aquifer of low potentiality is developed in the fractured crystalline formations. The discharge of the deep boreholes in the ophiolitic rocks does not exceed $30 \mathrm{~m}^{3} / \mathrm{h}$. Within the Neogene sandy and carbonate horizons an aquifer of low potentiality also occurs. The discharge of the boreholes, when the formation thickness and structure are favourable, reaches the $20-30 \mathrm{~m}^{3} / \mathrm{h}$.

\section{Materials and methods}

\subsection{Groundwater sampling and analysis}

After measuring the water temperature of several irrigation boreholes of the area, 12 groundwater samples were collected from irrigation wells with the highest temperature values (Table 1, Fig. 2). Unstable parameters such as, $\mathrm{pH}$, Temperature, Electrical Conductivity (E.C.) were measured in the field. All the samples were vacuum filtered, acidified to a final concentration of $2 \%$ nitric acid, stored in polyethylene bottles and preserved in a refrigerator.

All the 12 water samples were analyzed in the Laboratories of Institute of Geological and Mineralogical Exploration (I.G.M.E.). The major element and anion concentrations were measured using spectrophotometer, or/and titration or/and Atomic Absorption Spectroscopy (AAS) or and Inductively Coupled Plasma-Optical Emission Spectrometry (ICP-OES) (Table 2). The trace element concentrations were measured using Inductively Coupled Plasma-Mass Spectrometry (ICPMS) (Table 2).

ArcGIS software was used to create a digital geological map of the greater area of Eastern Thessaly (scale 1:70,000, Fig. 1). This map is based on the published geological map of scale 1:1,000,000 (Mataragkas et al., 2000). A spatial database was developed in ArcGIS; physicochemical parameters and elemental concentrations were linked to the sampling points and were used in order to create the probability map of temperature using the Surfer software (Fig. 2). 




\begin{tabular}{|c|c|c|c|c|}
\hline (ख) & $\begin{array}{l}\text { INSTITUTE OF GEOLOGICAL AND MINE } \\
\text { EXPLORATION (I.G.M.E.) }\end{array}$ & & GEOLOGICAL MAP O & $\begin{array}{l}\text { F EASTERN THESSALY } \\
\text { SCALE 1: } 700,000 \\
\end{array}$ \\
\hline & LEGE & & & \\
\hline Geol & al formation & & & \\
\hline & $\begin{array}{l}\text { POST-TECTONIC \& LATE-TECTONIC } \\
\text { HOLOCENE }\end{array}$ & PE4 & $\begin{array}{l}\text { JURASSIC } \\
\text { Schist-chert formation: ch } \\
\text { white limestone lenses an }\end{array}$ & $\begin{array}{l}\text { sandstone, pelite with } \\
\text { nclosed ophiolitic bodies }\end{array}$ \\
\hline MB1 & Recent deposits on valleys, plains and coasts & & LOWER TRIASSIC - J & URASSIC \\
\hline & PLEISTOCENE & PE5 & Limestone and dolomite, & cally of the Hallstatt facies \\
\hline MB4 . & $\begin{array}{l}\text { Marine deposits: marl, clay, sand, conglomerate, } \\
\text { marine terraces }\end{array}$ & & ME & 《S \\
\hline & $\begin{array}{l}\text { PLIO - PLEISTOCENE } \\
\text { Lacustrine and fluviolacustrine deposits: sand, cong }\end{array}$ & & $\begin{array}{l}\text { HODOPE \& SER } \\
\text { PELAGONIA }\end{array}$ & $\begin{array}{l}\text { ONIAN MASSIFS, } \\
\text { DES ZONES }\end{array}$ \\
\hline MB5: & $\begin{array}{l}\text { clay, peat of lignite beds, occasionally terra rossa } \\
\text { UPPER MIOCENE - PLIOCENE }\end{array}$ & M1 & Gneiss, amphibolite, schis & with marble intercalations \\
\hline MB7 & $\begin{array}{l}\text { UPPER MIOCENE - PLIOCENE } \\
\text { Lacustrine and terrestrial deposits: conglomerate, sand, } \\
\text { marl, marly limestone, terra rossa, clay, occasionaly lignite }\end{array}$ & M2 & Chlorite, mica, quartz sch & st, often with marble intercalations \\
\hline & NEOGENE UNDIVIDED & & & \\
\hline MB12 & $\begin{array}{l}\text { Lacustrine and marine deposits: conglomerate, sandstone, } \\
\text { marl, clay occasionally with lignite beds }\end{array}$ & M5 & Marble or crystalline limes & \\
\hline & OLIGOCENE & & IGNEOUS ROCKS & \\
\hline MB13 & Molassie formations: clay, conglomerate, sandstone, marl & PY2 & Mafic and ultramafic: gab & oro, spilite, pillow lavas. \\
\hline 01 & OSSA UNIT & PY3 & $\begin{array}{l}\text { Diabase, peridotite, dur } \\
\text { generally ophiolite }\end{array}$ & pyroxenite, serpintinite and \\
\hline 02 & $\begin{array}{l}\text { MESOZOIC - PALAEOCENE } \\
\text { Marlble and dolomite }\end{array}$ & Geolo & $\begin{array}{l}\text { ogical line } \\
\text { thrust fault }\end{array}$ & $\begin{array}{l}\text { Area of potential } \\
\text { geothermal interest }\end{array}$ \\
\hline & PELAGONIAN ZONE & & & \\
\hline PE1 & Flysch & & fault probable & Water point \\
\hline PE2 & $\begin{array}{l}\text { UPPER CRETACEOUS } \\
\text { Flyschoid of the upper cretaceous transgression, limestone- } \\
\text { crystalline limestone and marble }\end{array}$ & - & $\begin{array}{l}\text { tectonic contact or irregular } \\
\text { tectonic contact observed } \\
\text { fold axis }\end{array}$ & or gethermal drill \\
\hline
\end{tabular}

Figure 1 - Simplified geological map of eastern Thessaly (Mataragkas et al., 2000), presenting areas with hot and mineral springs and areas which are potentially interesting for geothermal energy data. 
Table 1 - Samples locality, physiochemical parameters, hydrochemical type and chemical geothermometers.

\begin{tabular}{|c|c|c|c|c|c|c|c|c|c|c|c|c|}
\hline \multirow[b]{2}{*}{ Code } & \multirow[b]{2}{*}{ Locality } & \multirow[b]{2}{*}{ Lon. $^{* 1}$} & \multirow[b]{2}{*}{ Lat. $^{* 1}$} & \multirow[b]{2}{*}{$\begin{array}{l}\text { Depth } \\
(\mathbf{m})\end{array}$} & \multirow[b]{2}{*}{$\begin{array}{c}\mathrm{T} \\
\left({ }^{\circ} \mathrm{C}\right)\end{array}$} & \multirow[b]{2}{*}{ pH } & \multirow{2}{*}{$\begin{array}{l}\text { TDS }^{* 2} \\
(\mathrm{mg} / \mathrm{lt})\end{array}$} & \multirow[b]{2}{*}{$\begin{array}{c}\text { EC } \\
(\mathrm{mS} / \mathrm{cm})\end{array}$} & \multirow{2}{*}{$\begin{array}{c}\text { Hydrochemical } \\
\text { type }\end{array}$} & \multicolumn{3}{|c|}{ Chemical geothermometers } \\
\hline & & & & & & & & & & $\mathrm{Qtz}^{* 3}$ & Chalcedony $^{* 3}$ & $\mathrm{Na}-\mathrm{K}-\mathrm{Ca}^{*}$ \\
\hline GTHES-001-D01 & Ampelia & 369248.59 & 4352419.58 & 410 & 41 & 8.1 & 310 & 458 & $\mathrm{Na}-\mathrm{HCO}_{3}$ & 105 & 75 & 41 \\
\hline GTHES-006-D03 & Ampelia & 369552.34 & 4352218.85 & 235 & 35 & 8.6 & 305 & 393 & $\mathrm{Na}-\mathrm{HCO}_{3}$ & 99 & 68 & 45 \\
\hline GTHES-037-D05 & Stefania & 369243.00 & 4353410.00 & 300 & 23 & 7.6 & 430 & 651 & $\mathrm{Ca}-\mathrm{Na}-\mathrm{HCO}_{3}$ & 63 & 31 & 107 \\
\hline GTHES-045-D08 & Ampelia & 368420.00 & 4352254.00 & 120 & 22 & 7.6 & 540 & 809 & $\mathrm{Ca}-\mathrm{Mg}-\mathrm{Na}-\mathrm{HCO}_{3}$ & 71 & 39 & 14 \\
\hline GTHES-046-D11 & Ampelia & 369854.46 & 4351525.20 & 120 & 23 & 7.2 & 1100 & 1575 & $\mathrm{Ca}-\mathrm{Mg}-\mathrm{Na}-\mathrm{HCO}_{3}-\mathrm{Cl}-\mathrm{SO}_{4}$ & 71 & 39 & 26 \\
\hline GTHES-058-D12 & Mnimata & 369100.73 & 4349245.65 & 300 & 26.3 & 7.6 & 570 & 857 & $\mathrm{Na}-\mathrm{HCO}_{3}-\mathrm{Cl}$ & 68 & 36 & 29 \\
\hline GTHES-095-D17 & Ampelia & 366831.00 & 4351721.00 & 120 & 17.4 & 7.3 & 626 & 995 & $\mathrm{Ca}-\mathrm{Mg}-\mathrm{HCO}_{3}$ & - & - & - \\
\hline GTHES-098-D18 & Ampelia & 368828.00 & 4351353.00 & 150 & 23.5 & 7.0 & 718 & 1180 & $\mathrm{Ca}-\mathrm{Mg}-\mathrm{HCO}_{3}-\mathrm{Cl}$ & 77 & 46 & 204 \\
\hline GTHES-093-D-14 & Ampelia & 368813.00 & 4350863.00 & 200 & 30.3 & 8.3 & 304 & 510 & $\mathrm{Na}-\mathrm{HCO}_{3}-\mathrm{Cl}$ & 57 & 25 & 35 \\
\hline
\end{tabular}

Table 2 - Concentrations of major anions and trace elements (in $\mathrm{mg} / \mathrm{L}$ ).

\begin{tabular}{|c|c|c|c|c|c|c|c|c|c|c|c|c|c|c|c|c|c|c|c|c|c|c|c|c|c|}
\hline Sample & $\begin{array}{l}\mathbf{C a}^{2+} \\
\mathrm{mg} / \mathrm{L}\end{array}$ & $\begin{array}{l}\mathbf{M g}^{2+} \\
\mathrm{mg} / \mathrm{L}\end{array}$ & $\begin{array}{c}\mathrm{Na}^{+} \\
\mathrm{mg} / \mathrm{L}\end{array}$ & $\begin{array}{c}\mathbf{K}^{+} \\
\mathrm{mg} / \mathrm{L}\end{array}$ & $\begin{array}{c}\mathrm{HCO}_{3}{ }^{-} \\
\mathrm{mg} / \mathrm{L}\end{array}$ & $\begin{array}{c}\mathbf{C l}^{-} \\
\mathrm{mg} / \mathrm{L}\end{array}$ & $\begin{array}{l}\mathbf{S O}_{4}{ }^{2-} \\
\mathrm{mg} / \mathrm{L}\end{array}$ & $\begin{array}{l}\mathbf{N O}_{3}^{-} \\
\mathrm{mg} / \mathrm{L}\end{array}$ & $\begin{array}{l}\mathbf{N H}_{4}{ }^{+} \\
\mathrm{mg} / \mathrm{L}\end{array}$ & $\begin{array}{l}\mathbf{N O}_{2}^{-} \\
\mathrm{mg} / \mathrm{L}\end{array}$ & $\begin{array}{l}\mathrm{SiO}_{2}^{-} \\
\mathrm{mg} / \mathrm{L}\end{array}$ & $\begin{array}{c}\mathbf{L i} \\
\mu \mathrm{g} / \mathrm{L}\end{array}$ & $\begin{array}{c}\mathbf{C r} \\
\mu \mathrm{g} / \mathrm{L}\end{array}$ & $\begin{array}{c}\mathbf{N i} \\
\mu \mathrm{g} / \mathrm{L}\end{array}$ & $\begin{array}{c}\mathbf{F} \\
\mu \mathrm{g} / \mathrm{L}\end{array}$ & $\begin{array}{c}\text { B } \\
\mu \mathrm{g} / \mathrm{L}\end{array}$ & $\begin{array}{c}\mathbf{F e} \\
\mu \mathrm{g} / \mathrm{L}\end{array}$ & $\begin{array}{c}\mathbf{S r} \\
\mu \mathrm{g} / \mathrm{L}\end{array}$ & $\begin{array}{c}\mathbf{B a} \\
\mu \mathrm{g} / \mathrm{L}\end{array}$ & $\begin{array}{c}\mathbf{A l} \\
\mu \mathrm{g} / \mathrm{L}\end{array}$ & $\begin{array}{c}\mathbf{B r} \\
\mu \mathrm{g} / \mathrm{L}\end{array}$ & $\begin{array}{c}\mathbf{A s} \\
\mu \mathrm{g} / \mathrm{L}\end{array}$ & $\begin{array}{c}\mathbf{C u} \\
\mu \mathrm{g} / \mathrm{L}\end{array}$ & $\begin{array}{c}\mathbf{H g} \\
\mu \mathrm{g} / \mathrm{L}\end{array}$ & $\begin{array}{c}\mathbf{U} \\
\mu \mathrm{g} / \mathrm{L}\end{array}$ \\
\hline GTHES-001-D01 & 8.9 & 4.1 & 87.8 & 0.9 & 209 & 27.7 & 19.3 & 1.86 & 0.216 & 0.41 & 53.2 & $<5$ & $<5$ & $<5$ & 320 & 1900 & 90 & 55 & 27 & 17 & - & $<5$ & $<5$ & $<0,5$ & $<5$ \\
\hline 6-D03 & 9.7 & 4 & 91 & 1.1 & & 23.8 & 228 & bld & 0.537 & 0.175 & 46.7 & 7 & 10 & $<5$ & 58 & 5400 & 88 & 50 & 29 & 34 & & 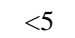 & $<5$ & $<0,5$ & $<5$ \\
\hline GTHES-036-D04 & 89.2 & 64.3 & 63.1 & 0.96 & 420 & 70.9 & 66.7 & 161 & .05 & $<0.05$ & 27.7 & 23 & $<5$ & $<5$ & 668 & 23 & 21 & 790 & & 11 & 890 & $<5$ & 14 & $<0,5$ & $<5$ \\
\hline THES-037-D05 & 31.6 & 14.5 & 99 & 2.55 & & 28.4 & .3 & 5.8 & 55 & $<0.05$ & 9.9 & 15 & $<5$ & $<5$ & 552 & 165 & 18 & 190 & 0 &, 5 & 470 & $<5$ & 6 & $<0,5$ & $<5$ \\
\hline STHES-0 & 68.1 & 41.3 & 52.9 & 1.34 & 40 & 39 & 26.6 & 33.5 & $<0.05$ & $<0.05$ & 24.1 & 22 & $<5$ & $<5$ & 430 & 53 & 190 & 495 & 24 & 104 & - & $<5$ & 8 & $<0,5$ & $<5$ \\
\hline -D11 & 100.6 & 99.71 & 104 & 2.34 & & 145.4 & 1 & 18.8 & 5 & 0.218 & 24.1 & 57 & $<5$ & 18 & 724 & 114 & 2020 & 903 & 150 & 500 & 1550 & $<5$ & 73 & $<0,5$ & $<5$ \\
\hline THES-058-D12 & 28.9 & 19 & 139.3 & 1.07 & 323 & 94 & 49.1 & 3.9 & $<0.05$ & $<0.05$ & 22.3 & 18 & $<5$ & $<5$ & 505 & 166 & 2950 & 167 & 138 & 36 & 1130 & 9 & 8 & $<0,5$ & $<5$ \\
\hline -D19 & 36.4 & 27.4 & 73.8 & 1. & & 44.3 & 72.8 & 19.84 & 5 & 0.08 & 15.9 & 13 & $<5$ & $<5$ & 620 & 190 & 200 & 26 & 40 & 150 & 600 & $<5$ & $<5$ & $<0,5$ & $<5$ \\
\hline D16 & 42.5 & 44.42 & ${ }^{2}$ & 0 . & & & & & 5 & & & . & $<5$ & $<5$ & 23 & 94 & 40 & 12 & - & $2 \xi$ & 50 & $<5$ & $<5$ & $<0,5$ & $<5$ \\
\hline THES-095-D17 & 96.7 & 53 & 29 & 0.91 & 391 & 30 & 88.5 & 109.75 & $<0.05$ & $<0.05$ & 25.5 & $<5$ & $<5$ & 6 & 420 & 33 & 10 & 220 & 20 & 18 & 500 & $<5$ & $<5$ & $<0,5$ & $<5$ \\
\hline 018 & 81.4 & 67.5 & 1 . & 1.5 & 44 & 89 & 58 & 109.13 & - & 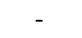 & 28.4 & 25 & $<5$ & $<5$ & 51 & 65 & 10 & 720 & $32-2>2$ & 12 & 1100 & $<5$ & 7 & $<0,5$ & $<5$ \\
\hline THES-093-D-14 & 9.39 & 2.2 & 103 & 0.71 & 195 & 43.6 & 30.9 & 0.62 & $<0.05$ & 0.48 & 17 & $<5$ & $<5$ & $<5$ & 100 & 650 & 75 & 34 & 21 & 31 & 500 & $<5$ & 15 & $<0,5$ & $<5$ \\
\hline
\end{tabular}




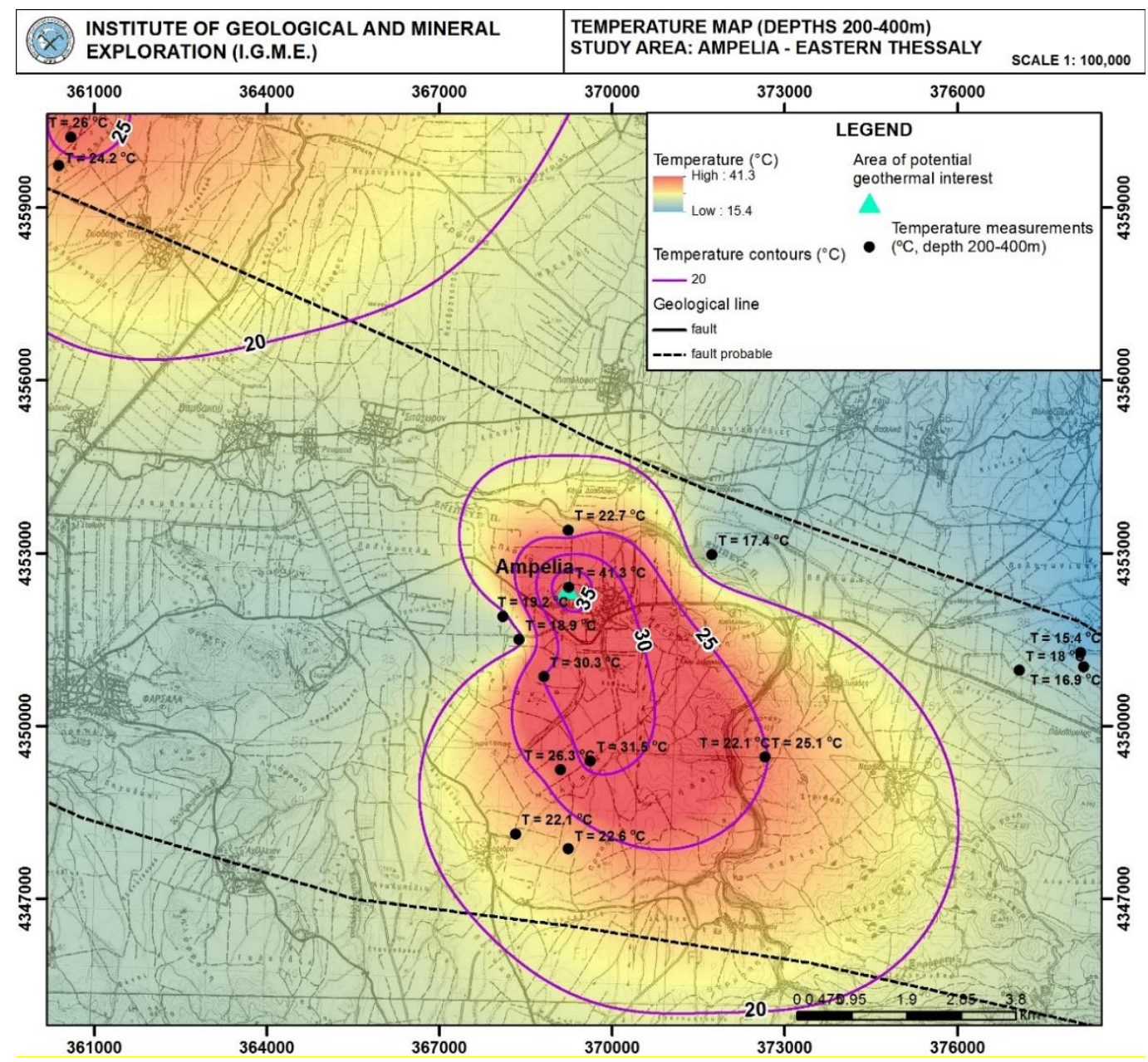

Figure 2 - Groundwater temperature distribution in Ampelia area, based on boreholes with depth $>200 \mathrm{~m}$.

\section{Analytical results}

\subsection{Spatial distribution of temperature}

In order to visualize the spatial distribution of the hot groundwater temperature an interpolated map was created based on boreholes with depth $>200 \mathrm{~m}$, using Kriging method (Fig. 2). Kriging is a deterministic interpolation method that generates an estimated surface from a scattered set of points with z-values, in this case water temperature values.

In Figure 2, the interpolated map reveals that the geothermal anomaly is constrained by the E-W trending faults, which mainly control the basin development and presents a direction N.NW-S.SE similar with N.NW-.SSE trending faults of the area. Also, reveals another geothermal anomaly in Zodochou Pigi area (NW edge of the map, Fig. 2). 

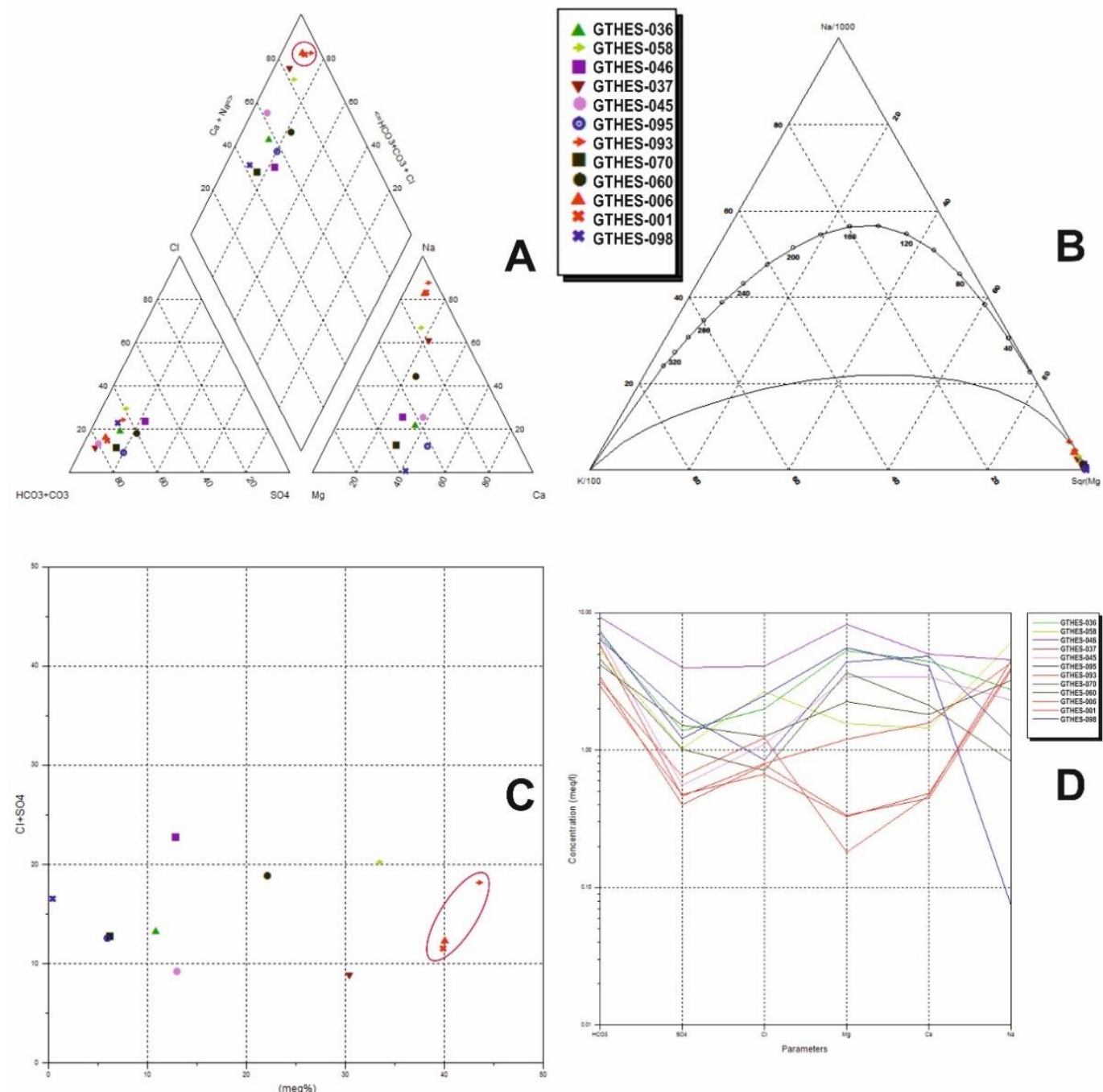

Figure 3 - Chemical composition of groundwater samples plotted in (A) Piper trilinear diagram. (B) Giggenbach trilineardiagram. (C) Ludwing-Langelier diagram. (D) Schoeller diagram. The three samples with temperature value over $30^{\circ} \mathrm{C}$ are symbolized with red color.

\subsection{Chemical Analysis}

The locations of the samples are presented in Figure 2 and in Tables 1 and 2 are presented the chemical parameters analyzed in situ and in the lab.

All samples present temperature values over $20^{\circ} \mathrm{C}$, except the sample GTHES-095-D17 which present temperature value $17.4^{\circ} \mathrm{C}$. The GTHES-006-D03 and GTHES-093-D-14 samples present temperature value over $30^{\circ} \mathrm{C}$ and the GTHES-001-D01 over $40^{\circ} \mathrm{C}$. These three samples show the lowest Electrical Conductivity $(393-510 \mathrm{mS} / \mathrm{cm})$ and the highest $\mathrm{pH}$ values $(\mathrm{pH}>8)$ compared with the rest of the samples.

In Figure 3A, the results of the chemical analyses were plotted in Piper diagram (Piper, 1953), in order to evaluate them hydrochemically and identify their hydrochemical type. The three samples with $\mathrm{T}>30^{\circ} \mathrm{C}$ are plotted, in the Piper and Ludwing-Langelier diagrams (Langelier and Ludwing, 1942, Fig. 3A, C) in the same area, while the rest of the samples are plotted scatter in the diagrams 
(Fig. 3A, C). The three samples with $\mathrm{T}>30^{\circ} \mathrm{C}$ have $\mathrm{Na}-\mathrm{HCO}_{3}$ as hydrochemical type supplemented by $\mathrm{Cl}$ for the GTHES-093-D-14 (Table 1). Also, they present the lowest concentrations of $\mathrm{Ca}^{2+}$, $\mathrm{Mg}^{2+}, \mathrm{HCO}_{3}{ }^{-}$and $\mathrm{NO}_{3}{ }^{-}$. Even though, the chemical composition of the samples varies in all the measured chemical parameters; these three samples show only small variation, characteristic is the diagram Schoeller (Fig. 3D, Table 2).

\subsection{Geothermometry application}

Chemical geothermometers are widely used tools in order to estimate the subsurface reservoir temperatures in a geothermal system (Giggenbach, 1988). Geothermometers are based on the equilibrium of temperature-dependent reactions between minerals and the circulating fluids (Fournier, 1973). Three geothermometers i.e. Quartz (Fournier, 1977), Chalcedony (Fournier, 1977) and Na-K-Ca (Fournier, 1979), were applied to the hot groundwaters of Ampelia (Table 1).

According to Giggenbach's (Fig. 2B) triangle diagram all the samples are plotted between the fields of non-equilibrated and partially equilibrated waters, meaning that they can't be considered equilibrated with minerals in the reservoir rock. For that reason, the chemical geothermometers give temperatures, which are diverse from one geothermometer to another and very variable between samples (Table 1). Another cause for that is the mixing of the hot groundwater with groundwater from swallower cold aquifers of the area. Therefore, the initial reservoir temperature could not be clearly estimated.

The estimated temperatures of the samples GTHES-001-D01, GTHES-006-D03 and GTHES-093D-14 could be considered as indicative for the temperature estimation of a potential subsurface reservoir. Based on these three samples, the estimated temperatures by Na-K-Ca geothermometer, are from 35 to $45^{\circ} \mathrm{C}$. That temperature range is very close to the maxima measured temperature. Silica geothermometers are typically inferred to reflect recent and/or shallower geothermal-reservoir temperatures (Fournier, 1981; Giggenbach, 1988; Ayling and Moore, 2013). For that reason, they are more suitable in the case of Ampelia. According to Quartz geothermometer, the calculated temperatures range from 57 to $105^{\circ} \mathrm{C}$ and based on the Chalcedony geothermometer the calculated temperatures range from 25 to $75^{\circ} \mathrm{C}$.

\section{Discussion - Conclusions}

The study area is located in Farsala basin which is part of the Western Thessaly basin (Fig. 1). More specifically, Ampelia area belongs to the Enipeas graben. The sediments filling of the basin are mainly Holocene alluvial sands and Pleistocene terrestrial sediments. The alpine basement is formed by flysch, Cretaceous limestones and ophiolitic rocks (Fig. 1). The morphology of the top of the basement is controlled by the neotectonic activity, expressed by large folds with axis direction NESW as well as by E-W and NW-SE striking faults (Spyridonos et al., 2002).

Even though in Ampelia area, no surface expression of geothermal system exists, the temperature values from the deep water boreholes (> $200 \mathrm{~m}$ depth) range from 20 to $41^{\circ} \mathrm{C}$. The Farsala Basin tectonic regime, combined with the existence of permeable and impermeable formations, create appropriate conditions for the development of an active geothermal system (Xatzis, 2001; Stamatis et al., 2007). The geothermal anomaly observed in the study area seems to be directly connected to the fractured zones by active fault system of the sub-basement formations. Based on the interpolated map (Fig. 2) the geothermal anomaly is constrained by the E-W trending faults, which mainly control the basin development and presents a direction NNW-SSE similar with NNW-SSE trending faults of the area.

The chemical composition of the studied groundwater samples varies in all chemical parameters. Characteristic are the several different hydrochemical types of the samples (Table 1) and the scattered projections of them in the discrimination diagrams i.e. Piper, Ludwing-Langelier and Schoeller (Fig. 2A, C, D). Most of the samples have high Electrical Conductivity values (up to 1575 $\mathrm{mS} / \mathrm{cm}$ ) and at the same time they present high concentrations in $\mathrm{NO}_{3}^{-}$(up to $109 \mathrm{mg} / \mathrm{L}$ ), revealing 
relation to the shallow cold aquifers which are affected from fertilizers. All these suggest that there is a mixing of the deep hot groundwater with shallower cold aquifers.

The most representative samples of the deep hot groundwater are the samples GTHES-001-D01, GTHES-006-D03 and GTHES-093-D-14. These samples have temperatures over $30^{\circ} \mathrm{C}$ and especially the GTHES-001-D01 which has the highest measured temperature $\left(41^{\circ} \mathrm{C}\right)$. It is interesting that all these boreholes have depth over $200 \mathrm{~m}$ and the deepest borehole of all (GTHES-001, $410 \mathrm{~m}$ depth) presents the highest temperature. In that borehole the main water supply originates from its deepest part, which is cutting the fractured crystalline basement i.e. karstified limestones, flysch and ophiolitic rocks. The $\mathrm{Ni}$ and $\mathrm{Cr}$ concentrations of these samples are very low, in most cases below detection limit, indicative that the groundwater is not in contact with the ultramafic rock from the ophiolite sequence. These three samples show the highest $\mathrm{pH}$ values $(\mathrm{pH}>8)$, the lowest Electrical Conductivity $(393-510 \mathrm{mS} / \mathrm{cm})$ and the lowest concentrations of $\mathrm{Ca}^{2+}, \mathrm{Mg}^{2+}, \mathrm{HCO}_{3}{ }^{-}$and $\mathrm{NO}_{3}{ }^{-}$ compared with the rest of the samples; indicative of the low degree of influence by the shallower cold aquifers which are degraded by the use of fertilizers. Characteristic is that these three samples show only small variation in most of the measured chemical parameters.

According to Giggenbach's triangle diagram (Fig. 2B) all the samples are plotted between the fields of non-equilibrated and partially equilibrated waters. It is also apparent that mixing of the deep hot groundwater with swallower cold aquifers, which have different chemistry, takes place for the majority of the samples. For these reasons, the resulting temperatures are different for each geothermometer and with large variations between samples (Table 1). However, the estimated temperatures for the samples GTHES-001-D01, GTHES-006-D03 and GTHES-093-D-14 from the silica geothermometers could be used as indicative for the estimation of the temperature a potential subsurface geothermal reservoir. According to their geothermometric estimations, the expected temperature values of a potential geothermal reservoir range from $\sim 60$ to $100^{\circ} \mathrm{C}$.

Many questions remain unanswered about the geothermal potential of Ampelia area e.g. about the underground circulation of the hot water; about the related reservoir etc. A systematic geothermal deep drilling project, will give valuable information concerning the geothermal potential of the region and it will help the economic development of the area.

\section{Acknowledgements}

This study was funded by the National Strategic Reference Framework (NSRF, 350913). The authors would like to thank the local population for their co-operation during the field work. The corresponding author would like to thank Dr. George Vougioukalakis who critically commented on an earlier version of this manuscript.

\section{References}

Ayling, B. and Moore, J., 2013. Fluid geochemistry at the Raft River geothermal field, Idaho, USA: New data and hydrogeological implications, Geothermics, 47, 116-126.

Aubouin, J., 1959. Contribution a l' etude geologique de la Grece septentrionale: les confins de l' Epire et de la Thessalie, Ann. Geol. Pays Hellen., 10, 1-483.

Dimitriou, D. and Arapogianni, E., 2000. Study and assessment of the lignite dynamic of Thessaly, IGME, Athens.

Fournier, R.O., 1973. Silica in thermal waters: laboratory and field investigations, Proc. International Symposium on Hydrogeochemistry and Biogeochemistry, 122-139 (Tokyo).

Fournier, R.O., 1977. Chemical geothermometers and mixing models for geothermal systems, Geothermics 5, 41-50.

Fournier, R.O., 1979. A revised equation for the Na/K geothermometer, Geoth. Resources Council, 3, 221-224. 
Fournier, R.O., 1981. Application of water geochemistry to geothermal exploration and reservoir engineering. In: Rybach, L. and Muffler, L.J.P., eds., Geothermal Systems: Principles and Case Histories, Wiley \& Sons, 109-143.

Giakkoupis, P., 1995. Report on the lignite in Ampelia-Kastro area (Farsala, Thessaly), IGME, Athens.

Giggenbach, W.F., 1988. Geothermal solute equilibria. Derivation of Na-K-Mg-Ca geoindicators, Geochim., Cosmochim., Acta, 52, 2749-2765.

Gioni, G., 1983. Inventory of hot and mineral springs of Greece, I, Aegean Sea, Hydrological and Hydrogeological Investigation Report No. 39, IGME, Athens (in Greek).

Glassley, W., 2015. Geothermal Energy: Renewable energy and the environment (Second edition), CRC Press, Taylor \& Francis Group.

Katsikatsos, G., Mylonakis, E., Triantaphyllis, E., Papadeas, G., Psonis, K., Tsaila-Monopoli, S. and Skourtsi-Koroneou, V., 1983. Geological Map of Greece 1:50.000, Velestino Sheet, Publication IGME Athens.

Mariolakos, E., Lekkas, S., Alexopoulos, A., Fountoulis, I., Spyridonos, E., Badekas, I., Mariolakos, D. and Andreadakis, E., 2001a. Artificial recharge of underground karst aquifer of Fylliiou Mountain in Farsala area (Thessaly), Proc. of the 9th Intern. Congr. Athens, September 2001, Bull. Geol. Greece, XXXIV/5, 1843-1850.

Mariolakos, E., Lekkas, S., Papadopoulos, T., Alexopoulos, A., Fountoulis, I., Alexopoulos, I., Spyridonos, E., Badekas, I., Mariolakos, D. and Andreadakis, E., 2001b. The subsurface tectonic structure of the Farsala basin (Thessaly) as determining factor of the Hydrogeologocal conditions of the region, Proc. of the 9th Intern. Congr. Athens, September 2001, Bull. Geol. Greece, XXXIV/5, 1851-1858.

Mataragkas, D., Triantafilli, M., Androulakakis, N., Stauridis, A. and Paraskeyopoulos, P., 2000. Geological Map of Greece 1:1.000.000, Publication IGME Athens.

Mountrakis, D., 1986. The Pelagonian zone in Greece. A polyphase-deformed fragment of the Cimmerian Continent and its role in the geotectonic evolution of the Eastern Mediterranean, Journal of Geology, 94, 335-347.

Mpornovas, I. and Filippakis, N., 1964. Geological Map of Greece 1:50.000, Farsala Sheet, IGME, Athens.

Mpornovas, I., Filippakis, N. and Bizon, J.J.G., 1969. Geological Map of Greece 1:50.000, Farsala Sheet, IGME, Athens.

Sfetsos, K.S., 1988. Inventory of hot and mineral springs of Greece, III, Mainland Greece. Hydrological and Hydrogeological Investigation Report No. 39, IGME, Athens (in Greek).

Spyridonos, E., Fountoulis, I., Andreadakis, E., Mariolakos, D. and Manutsoglu, E., 2002. Using Integrated 3D Geological Modelling for Planning Artificial Recharge of Karstic Groundwater. Case Study in the Enipefs River Basin, Thessaly, Greece, TERRA NOSTRA, Proc. 8th Annиal conference of the International Association for Mathematical Geology, 04/2002, 493-498.

Stamatis, G., Parpodis, K., Lambrakis, N. and Zagana, E., 2007. Origin and quality of thermal groundwaters in the region of farsala (E. Thessaly/Greece), Bull. Geol. Soc. Greece, XXXVII, 570-579.

Taktikos, S., 1985. Heat flow and underground temperature measurements, IGME, Athens (in Greek).

Xatzis, M., 2001. Study and assessment of the geothermal capacity of Thessaly, IGME, Athens (in Greek). 